\title{
Low Penetrance Allele
}

National Cancer Institute

\section{Source}

National Cancer Institute. Low Penetrance Allele. NCI Thesaurus. Code C48666.

A gene with a low probability of expression as a phenotype. 